\title{
Congenital herpes simplex virus infection
}

INSERM

\section{Source}

INSERM. (1999). Orphanet: an online rare disease and orphan drug data base. Congenital herpes simplex virus infection. ORPHA:293

Cong enital herpes virus infection is a group of anomalies that an infant may present as a result of maternal infection and subsequent foetal infection with herpes virus. This virus causes recurrent cutaneous infections in adults, often involving the lips or the genitalia. Herpes infections in other organs, such as the liver or central nervous system, are less frequent. 